\title{
MASS BALANCE OF FOUR CIRQUE GLACIERS IN THE TORNGAT MOUNTAINS OF NORTHERN LABRADOR, CANADA
}

\author{
By ROBERT J. ROGERSON
}

(Departments of Earth Sciences and Geography, Memorial University of Newfoundland, St. John's,

Newfoundland A1B 3X5, Canada)

\begin{abstract}
The net mass balance of four small cirque glaciers $\left(0.7-1.4 \mathrm{~km}^{2}\right)$ in the Torngat Mountains of northern Labrador was measured for 1981-84, allowing three complete mass-balance years to be calculated. The two largest glaciers experienced positive mass-balance conditions in 1982 while all the glaciers were negative in 1983. The temporal pattern relates directly to general climatic conditions, in particular winter snowfall. Spatial variations of mass balance on the glaciers are the result of several factors including altitude, extent of supraglacial debris cover, slope, proximity to side and backwalls of the enclosing cirque, and the height of the backwall above the ice surface. Abraham Glacier, the smallest studied and with consistently the largest negative mass balance $(-1.28 \mathrm{~m}$ in 1983), re-advanced an average of $1.2 \mathrm{~m}$ each year between 1981 and 1984 . Mean equilibrium-line altitude (ELA) for the four glaciers is $1050 \mathrm{~m}$, varying substantially from one glacier to another $(+240$ to $-140 \mathrm{~m})$ and from year to year $(+60$ to $-30 \mathrm{~m})$.
\end{abstract}

RÉSUMÉ. Bilan de masse de 4 glaciers de cirque dans les montagnes Torngat, Labrador septentrional, Canada. Le bilan de masse net de quatre petits glaciers de cirque $(0,7$ à $1,4 \mathrm{~km}^{2}$ ) dans les montagnes Torngat, Labrador septentrional, a été mesuré pour 1981-84, en permettant le calcul de trois années complètes de bilan de masse. Les deux plus grands glaciers ont connu des bilans de masse positifs en 1982 alors que tous ont été déficitaires en 1983. Ces caractéristiques temporelles sont dues aux conditions climatiques générales, notamment aux chutes de neige hivernales. Les variations spatiales du bilan de masse sur les glaciers sont dépendantes de plusieurs facteurs tels que l'altitude, l'extension superficielle de la couverture de débris,

\section{INTRODUCTION}

The Torngat Mountains in northern Labrador host the only glaciers in continental North America east of the Rocky Mountains and the southernmost glaciers in the Canadian eastern Arctic. The largest group of glaciers occurs south of Nachvak Fiord in the area of the Selamiut Range, the highest in the Torngat Mountains, yet an area which was overlooked in surveys of the glaciers of Labrador by Mercer (1958) and Fahn (1975).

The glaciers are all small $\left(<1.5 \mathrm{~km}^{2}\right)$ and most of them exist in deep cirques with high, overshadowing backwalls which are probably significant to their existence. Tanner (1944) questioned the continuing survival of "Miniaturgletscher" in the Torngat Mountains which he illustrated with two pictures of Bryants Glacier, c. $40 \mathrm{~km}$ north of the Selamiut Range. Taken in 1908 and 1931, the photographs indicate very substantial recession of the glacier. In recent years, Stix (unpublished) reported evidence that some glaciers in the Selamiut Range had re-advanced prior to 1979. It seems possible that glaciers in the Torngat Mountains may have rallied in response to climatic la pente, la proximité des rives et des parois fermant le cirque et la hauteur de ces parois au-dessus de la surface de la glace. Le Abraham Glacier, le plus petit de tous, doté indubitablement du bilan de masse le plus négatif $(-1,28 \mathrm{~m}$ en 1983) réavançait à la vitesse moyenne de $1,2 \mathrm{~m} / \mathrm{an}$ entre 1981 et 1984. L'altitude moyenne de la ligne d'équilibre (ELA) pour les quatre glaciers est de $1050 \mathrm{~m}$, variant notablement d'un glacier à l'autre $(+240$ à $-140 \mathrm{~m})$ et d'une année sur l'autre $(+60$ à $-30 \mathrm{~m})$.

ZUSAMMENFASSUNG. Massenbilanz für vier Kargletscher in den Torngat Mountains von Nord-Labrador, Kanada. Die Netto-Massenbilanz von vier kleinen Kargletschern $\left(0,7-1,4 \mathrm{~km}^{2}\right)$ in den Torngat Mountains von Nord-Labrador wurde für die Jahre 1981-84 gemessen; hieraus lassen sick drei vollständige Jahresmassenbilanzen berechnen. Die beiden grössten Gletscher wiesen 1982 positive Massenbilanzen auf; 1983 waren alle Bilanzen negativ. Die zeitliche Verteilung spiegelt direkt die allegemeinen klimatischen Verhältnisse wider, speziell den Schneefall im Winter. Răumliche Schwankungen der Massenbilanz auf den Gletschern sind das Ergebnis verschiedener Faktoren, darunter die Meereshöhe, das Ausmass der oberflächlichen Schuttbedeckung, die Neigung, die Nähe zu den Seiten- und Rückwänden der Kare, die Höhe der Rückwand über der Eisoberfläche. Der Abraham Glacier, der kleinste unter den untersuchten und mit stets grösster negativer Massenbilanz $(-1,28 \mathrm{~m}$ im Jahre 1983), rückte zwischen 1981 und 1984 im Jahresmittel um $1,2 \mathrm{~m}$ vor. Die Höhe der mittleren Gleichgewichtslinie (ELA) beträgt für die vier Gletscher $1050 \mathrm{~m}$, zeigt aber von Gletscher zu Gletscher wesentliche Unterschiede $(+240 \mathrm{~m}$ bis $-140 \mathrm{~m})$ und schwankt von Jahr zu Jahr $(+60 \mathrm{~m}$ bis $-30 \mathrm{~m})$.

deterioration evident in Baffin Island, and elsewhere in the Arctic, according to several indicators (Bradley and Miller, 1972; Bradley and England, 1977). This project began, therefore, with the objective of measuring the mass balance and terminal response of several glaciers, including the largest glacier in the Torngat Mountains.

\section{Torngat Mountains glaciers}

The glaciers selected for the program were Superguksoak, the largest glacier in the Torngat Mountain with an area of $1.4 \mathrm{~km}^{2}$ and Minaret Glacier, both in the high Selamiut Range, and Abraham and Hidden Glaciers in the Cirque Mountain Range (Fig. 1). All lie within reasonable walking distance of Ivitak Cove on Nachvak Fiord, which became the location for a base camp.

The glaciers are all cirque glaciers. Superguksoak Glacier might be described as a double cirque glacier since it is fed from two adjacent cirque basins. The cirques open towards the north-west in the case of Abraham and Hidden Glaciers and to the north-east in the case of Minaret Glacier. The terminal section of Superguksoak Glacier 


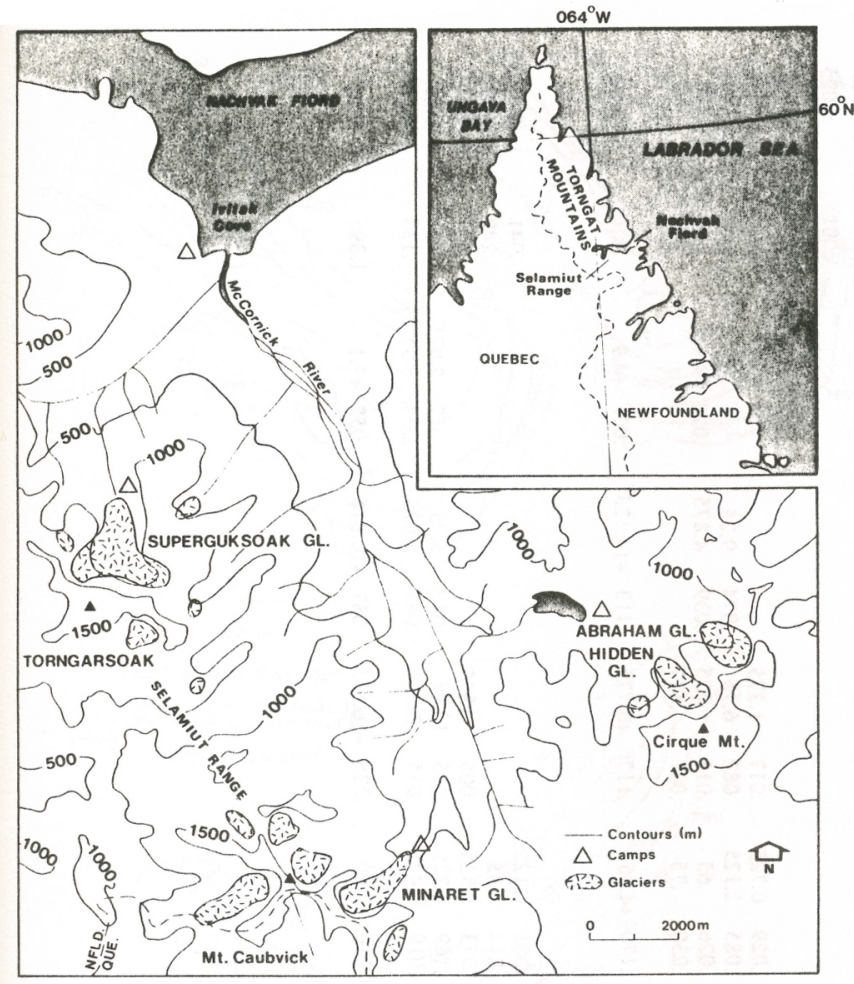

Fig. 1. Glaciers in the Selamiut and Cirque Mountain Ranges of the Torngat Mountains, northern Labrador.

points north. Three of the glaciers are very low in the cirques with $57-70 \%$ of their surface area between 800 and $1000 \mathrm{~m}$ (Fig. 2). They are overshadowed by very high backwalls which feed snow and debris to the firn down chutes or couloirs. Minaret Glacier is much higher with $62 \%$ of its surface area between 1200 and $1400 \mathrm{~m}$ (Fig. 2). Consequently, the backwall of Minaret Glacier is lower relative to the ice surface. A survey of ice depths using radio-echo sounder and EM-16 resistivity meter indicates maximum measured depths of $176 \mathrm{~m}$ for Superguksoak Glacier, $142 \mathrm{~m}$ for Minaret Glacier, and $55 \mathrm{~m}$ for Abraham Glacier (personal communication from C. Garrity).

\section{MASS-BALANCE METHODS}

Simple mass-balance measurements were made following the methods described in Østrem and Stanley (1966). Networks of aluminum poles were drilled into the glacier
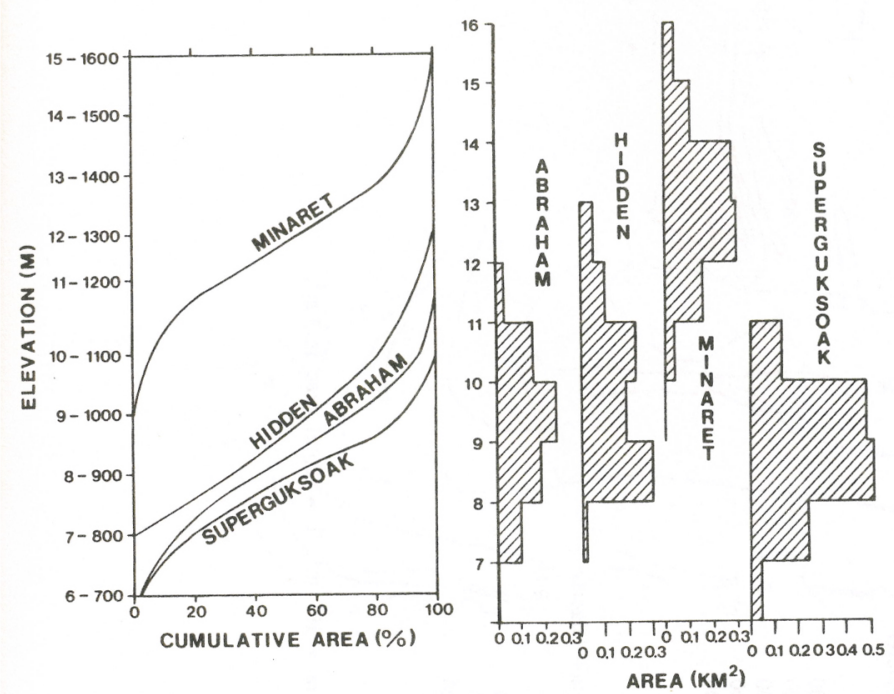

Fig. 2. Distribution of glacier surface area by altitude: cumulative curves of percentage total area, and histograms of area in $\mathrm{km}^{2}$. surfaces in July 1981, prior to the appearance of bare ice on Superguksoak Glacier and shortly after the first appearance of bare ice on the other glaciers. Initially, 11 poles were set in Superguksoak Glacier, ten in Minaret Glacier, and three in each of Abraham and Hidden Glaciers (Fig. 3). They were set at altitudes varying from $700 \mathrm{~m}$ to $1350 \mathrm{~m}$ a.s.1. Subsequently, the networks were expanded, particularly in 1983 when a detailed examination of ablation was undertaken (Branson, unpublished). At each site the change in snow- or ice-surface elevation could be measured relative to the pole.

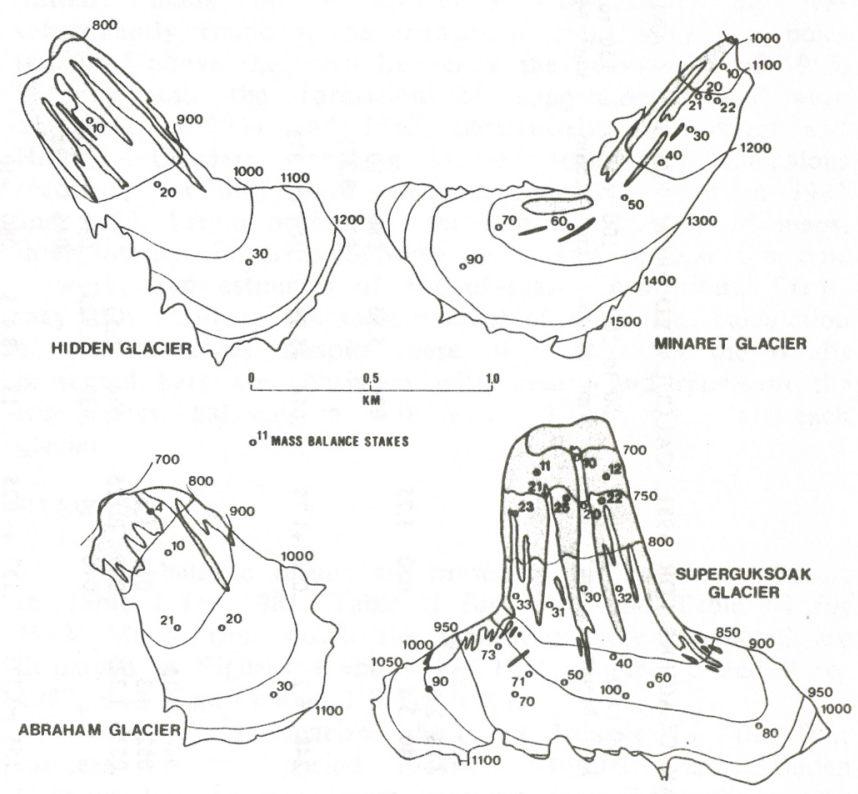

Fig. 3. Maps of mass-balance pole locations on four Torngat Mountains glaciers.

Measurements proceeded through each summer at irregular intervals, terminating in late August. By this time the first snow had fallen and in 1981 streams on the glacier were completely frozen. However, substantial amounts of melt occurred after the field season. These were evident in the first measurements of the following season when they were made with snow still covering the previous year's ablation surface.

No measurements of gross accumulation and gross ablation were made; such determinations require very long field seasons which are a problem in remote locations. The measurements obtained are of net accumulation (total quantity of snow left at the end of the melt season) and net ablation (total quantity of ice melted during the melt season), and mass balance of a glacier is calculated as the sum of these items. Since the end of the melt season is impossible to forecast or totally reconstruct beyond the pole locations from the first readings of the following year, some careful estimates are included in the calculations. All values are in units of water equivalent (w.e.) assuming a density of $0.9 \mathrm{~g} \mathrm{~cm}^{-3}$ for ice and using measured values of snow density.

Maps of the glaciers were drawn at scales of $1: 6250$ (Superguksoak Glacier), and 1:13 300 from air photographs, and from 1:50000 topographic maps. Pole elevations were checked with an altimeter. Superguksoak Glacier was also surveyed from several vantage points with a Brunton compass to triangulate the pole locations and glacier perimeter (Branson, unpublished).

Mass-balance values for each pole were entered on the maps. Isolines constructed on the maps owed much to the experience gained as the field season progressed, especially with respect to snow-line position, areas of slushing, and areas of sediment cover. Mass-balance quantities were obtained by the use of a planimeter on the contour maps (using a $\mathrm{Hi}$ State precision digitizer) and multiplying the areas by mean net mass-balance values. The sum of these quantities, divided by the area of the glacier concerned, is the mass balance for that year. 


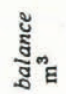

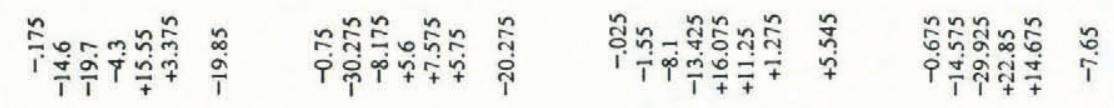

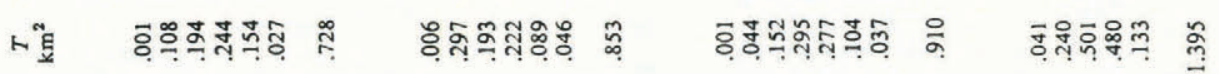

\begin{tabular}{|c|c|c|c|c|c|c|c|}
\hline 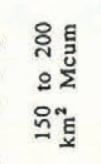 & & & & & \begin{tabular}{l}
$\stackrel{g}{+}$ \\
\multirow{\sigma}{*}{}
\end{tabular} & 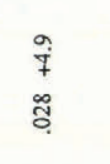 & 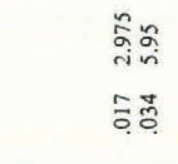 \\
\hline $\begin{array}{l}\frac{0}{0} \\
0 \frac{5}{2} \\
0.5\end{array}$ & ○总 & & สูก & ‡ & 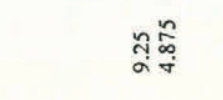 & $\stackrel{\ddot{g}}{\vec{j}}$ & วูสิ \\
\hline 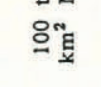 & ๕ัติ & $\stackrel{+}{9}$ & 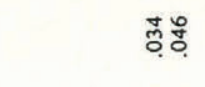 & $\stackrel{\circ}{\circ}$ & 䓂愛 & $\stackrel{m}{=}$ & 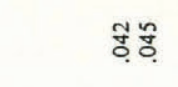 \\
\hline$\frac{8}{\frac{5}{2}}$ & ڤิ & $\stackrel{n}{\hat{n}}$ & ถึ่ & $\underset{\substack{n \\
\dot{q} \\
+\infty}}{+}$ & 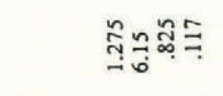 & $\underset{\substack{n \\
\dot{\phi}}}{\stackrel{n}{+}}$ & 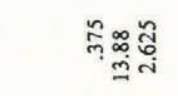 \\
\hline 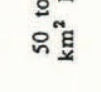 & ta & ț & 蓉高 & $\stackrel{m}{\rightrightarrows}$ & 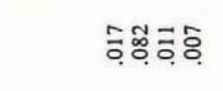 & $\fallingdotseq$ & 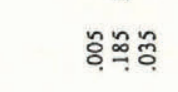 \\
\hline 官 & $\stackrel{\sim}{\leftrightarrows}$ & $\stackrel{n}{+}$ & 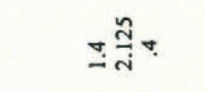 & $\underset{殳}{\stackrel{2}{q}}$ & 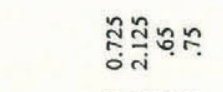 & $\stackrel{\nexists}{\ddagger}$ & ๘๓ฌส \\
\hline 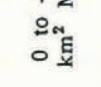 & $\stackrel{8}{a}$ & 苟 & 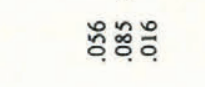 & $\stackrel{+}{5}$ & 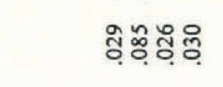 & $\stackrel{+}{9}$ & 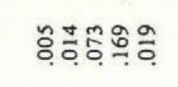 \\
\hline 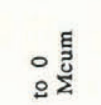 & 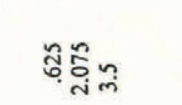 & $\tilde{\varphi}$ & $\dddot{m}=\stackrel{\partial}{=}$ & $\underset{\tilde{r}}{n}$ & 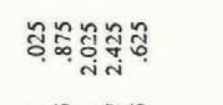 & $\tilde{i}$ & 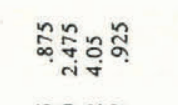 \\
\hline 䐻 & ํํำ & $\stackrel{\infty}{\vec{p}}$ & 웅ํํํํํ. & $\underline{n}$ & 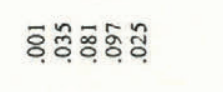 & ণิ & 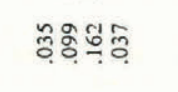 \\
\hline 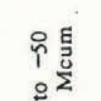 & สิสักิ & $\begin{array}{l}n \\
\hat{\varphi} \\
\varphi\end{array}$ & તુస్టిగ్ & के & ติ구ำ & $\frac{5}{1}$ & 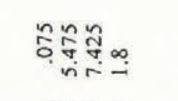 \\
\hline 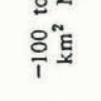 & วิำ & $\bar{a}$ & 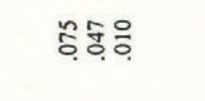 & $\cong$ & 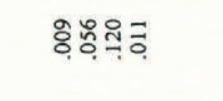 & $\stackrel{\circ}{\dddot{9}}$ & 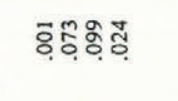 \\
\hline 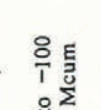 & 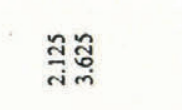 & $\grave{\hat{r}}$ & 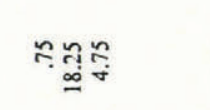 & in & 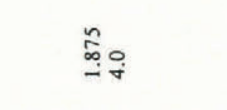 & $\stackrel{\Upsilon}{\stackrel{0}{\omega}}$ & ลิำ \\
\hline 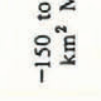 & స్తి & : & 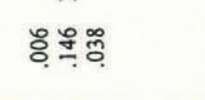 & $\stackrel{1}{9}$ & $\frac{n}{n} \tilde{a}$ & 울. & 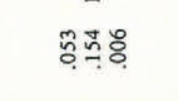 \\
\hline 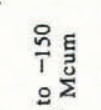 & 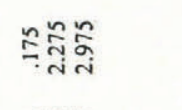 & 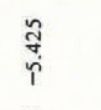 & $\approx$ & $\ddot{\ddot{r}}$ & & & ñ \\
\hline (1) & อุด. & $\overrightarrow{0}$ & \% & 高 & & & ปัะ \\
\hline 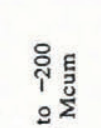 & 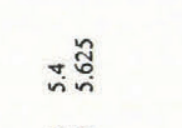 & $\stackrel{\stackrel{\partial}{\bar{T}}}{\stackrel{\bar{T}}{2}}$ & & & & & \\
\hline 政 & ఫ્ఠ઼્ఫ & : & & & & & \\
\hline 号息 & $\hat{i}_{m}$ & مें & & & & & \\
\hline 定 & 웅뭉 & ส & & & & & \\
\hline 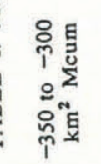 & & & & & & & \\
\hline$\Xi$ & 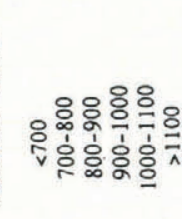 & 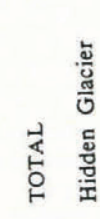 & 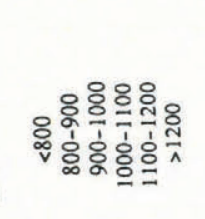 & 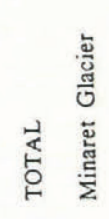 & 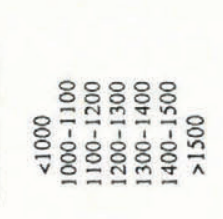 & 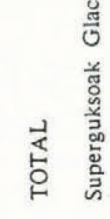 & 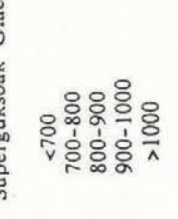 \\
\hline
\end{tabular}




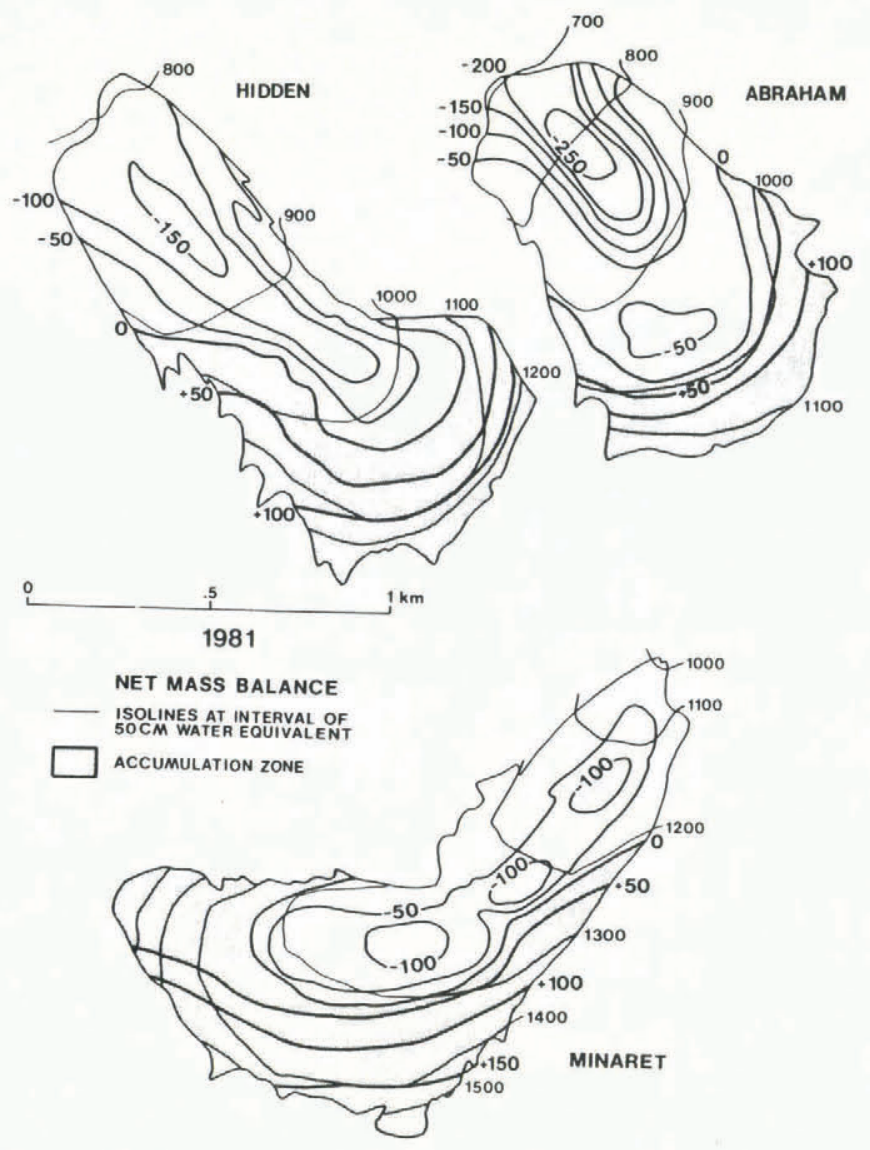

Fig. 4. Maps of net mass balance for 1981 for Abraham, Hidden, and Minaret Glaciers (see Table I).

\section{ERRORS AND DEFICIENCIES}

There are a number of potential sources of error in this work. Measuring errors may occur during the summer, particularly when excessive sun-cupping makes identification of the melt surface arbitrary. In this work, sun-cups were bridged with an ice-axe laid flat and measurements were made to the point where it crossed the pole. Detection of the firn surface beneath snow with a snow probe was seldom difficult, but it was not confirmed by digging pits at more than a few sites. The distribution of poles was initially made on a subjective basis, but this was subsequently found to be inadequate since very few poles remained above the snow line after the heavy melt of 1983 . Slushing and the formation of superimposed ice were dominant in 1981 and 1982, particularly on Minaret and Hidden Glaciers, causing some seemingly anomalous readings, yet they were almost completely absent in 1983 and 1984. Errors probably enter into the drawing of maps, interpretation in areas between poles and beyond the pole network, and estimates of end-of-season conditions. Errors may also occur in the measurement of areas and calculation of mass balances. Despite these, it is felt that the results presented here are consistent with reality and represent the true mass balance to within c. $0.1 \mathrm{~m}$ w.e. for each glacier.

\section{RESULTS}

Mass-balance results are presented for the four glaciers in Table I for 1981, Table II for 1982, and Table III for 1983. Maps from which the quantities were calculated are displayed in Figures 4 and 5 for 1981, Figures 6 and 7 for 1982, and Figures 8 and 9 for 1983.

Table IV summarizes the mass balance for the four glaciers for the period 1981-83. Abraham and Hidden Glaciers had negative mass balances throughout the period with the largest negative balance in 1983. Minaret and

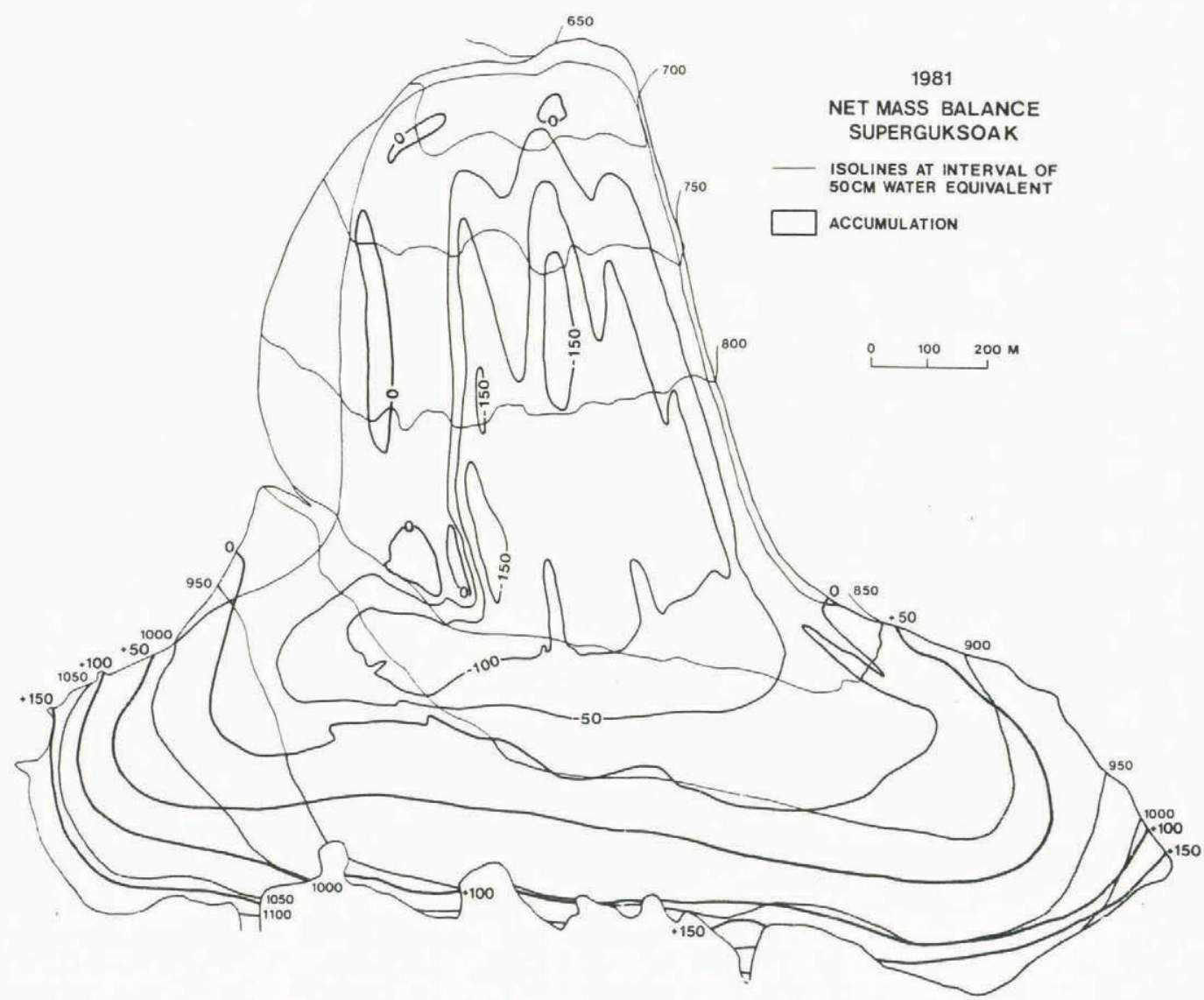

Fig. 5. Map of net mass balance for 1981 for Superguksoak Glacier (see Table I). 


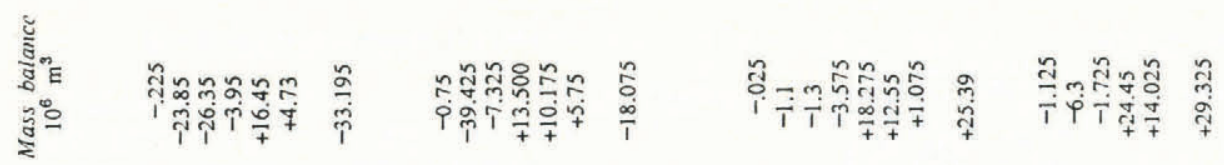

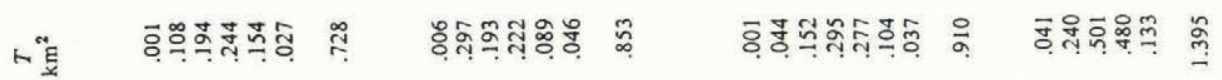

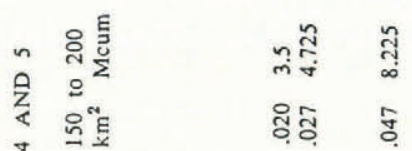

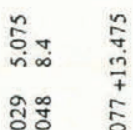

出

空

产

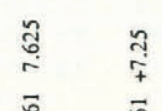

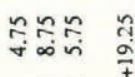

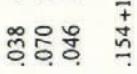

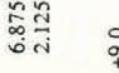

ถู่อิ

กำ

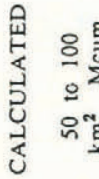

กิำ

\%े Э

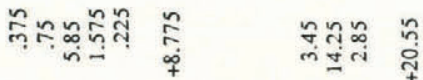

ถุำ

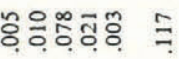

옹으유ำ

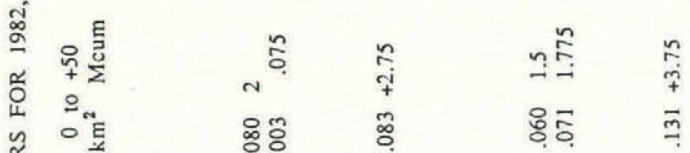

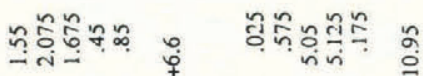
કุํำ

डิ

ชที่

紊

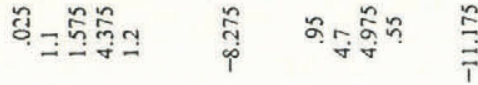

总

范誉

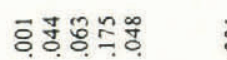

ถึ่

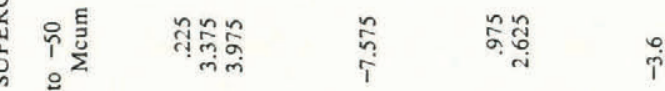

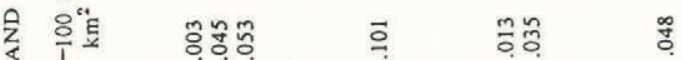

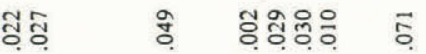

点

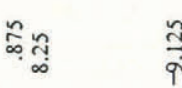

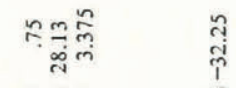

$\stackrel{n}{\frac{n}{i}}$

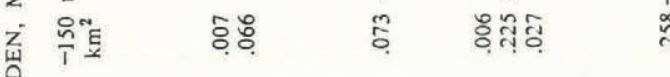

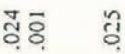

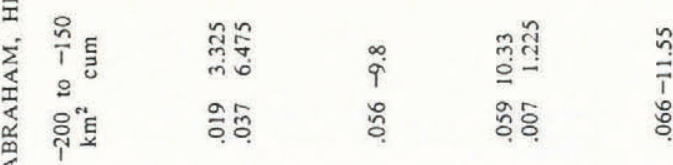

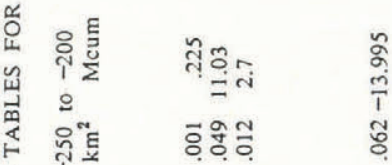

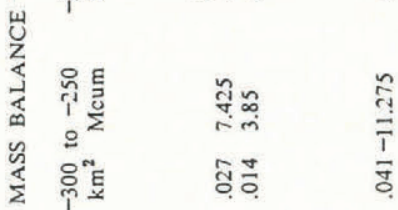

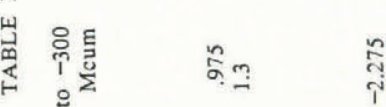

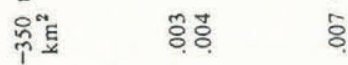

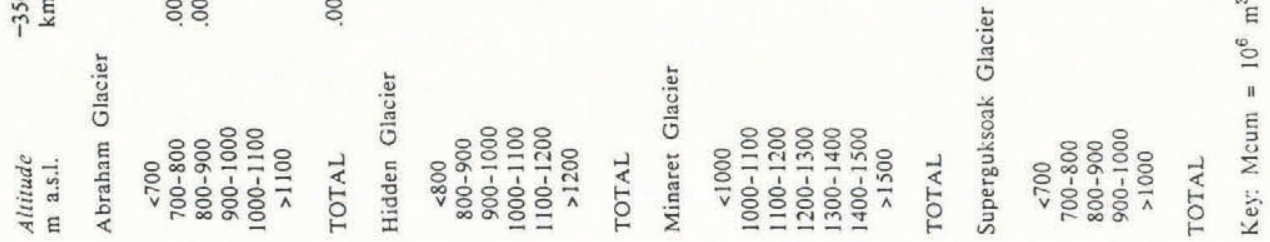




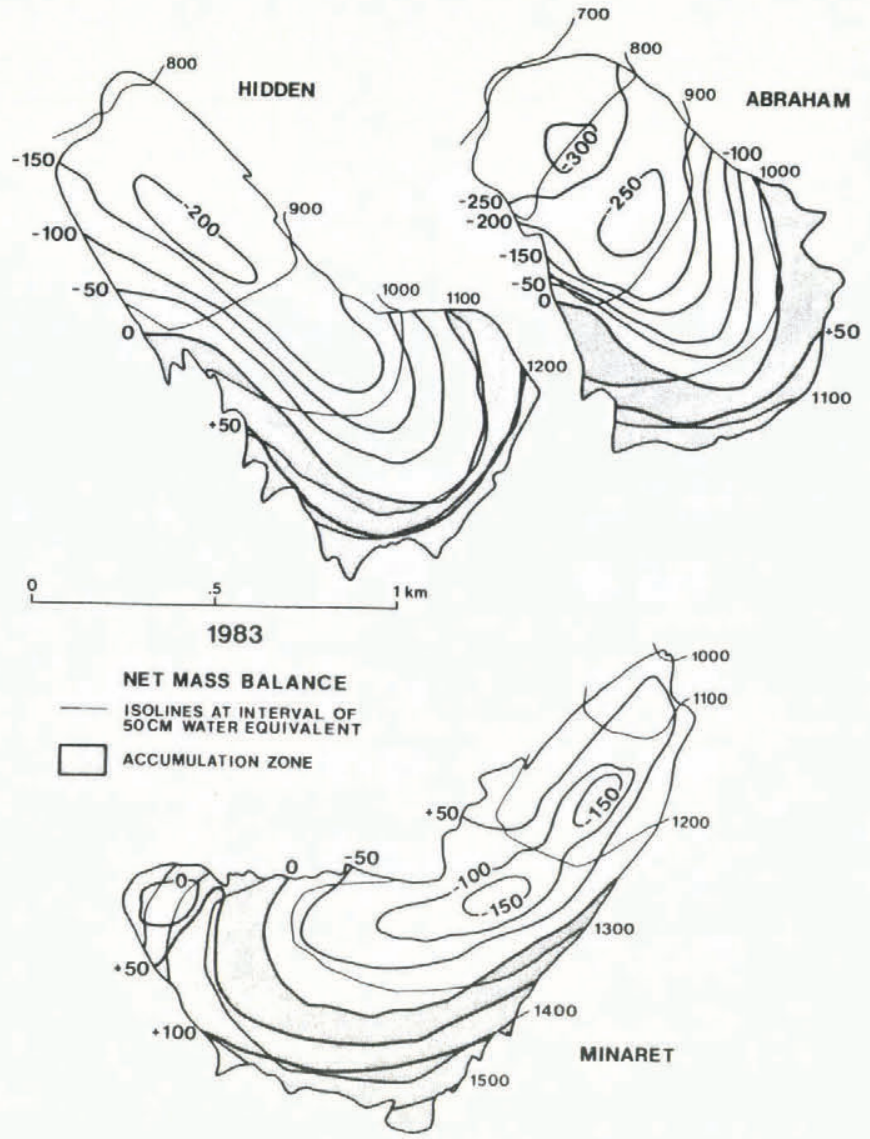

Fig. 6. Maps of net mass balance for 1982 for Abraham, Hidden, and Minaret Glaciers (see Table II).
Superguksoak Glaciers also had their largest negative balances in 1983. Both had small positive balances in 1982 and were almost zero in 1981.

Although climatic controls vary the mass balance from year to year, spatial patterns and variations from one glacier to another can probably be attributed to the salient physical characteristics of the glaciers.

\section{Superguksoak Glacier}

On this glacier, the highest negative balances occur not at low altitudes near the terminus but $50-200 \mathrm{~m}$ higher (Fig. 10). The area of large negative values lies close to the upglacier limit of thick supraglacial debris cover which forms characteristic medial moraines. On the medial moraines, ice melt is less than half that on bare ice since the debris insulates the ice from warm air and prevents the direct incidence of solar radiation (Rogerson and others, in press). In 1981 and 1982, snow patches survived in the hollows between the medial moraines through until the end of the melt season. In 1983 they all melted. In mid-July 1981 and 1982, the glacier was still entirely snow-covered except for the crests of medial moraines which presumably had been swept free of snow by the wind. In early July 1983, the snow line was already almost as high as the end-of-season snow line in 1982. This can be attributed to very low winter snowfall which affected all of northern Labrador and which resulted in the melting of many semi-permanent snow patches in the mountains. The shortage of snow cover exposed the dark ice surface to solar radiation far earlier in the summer, when the sun is close to its zenith, than in previous years, and this resulted in ablation values which, for many poles, were three to five times higher than in 1982.

\section{Minaret Glacier}

This glacier is the most unusual glacier and may not be typical of others in the Torngat Mountains. The terminus of the glacier slopes towards the north-east at a steep angle which keeps much of its surface in shade for a

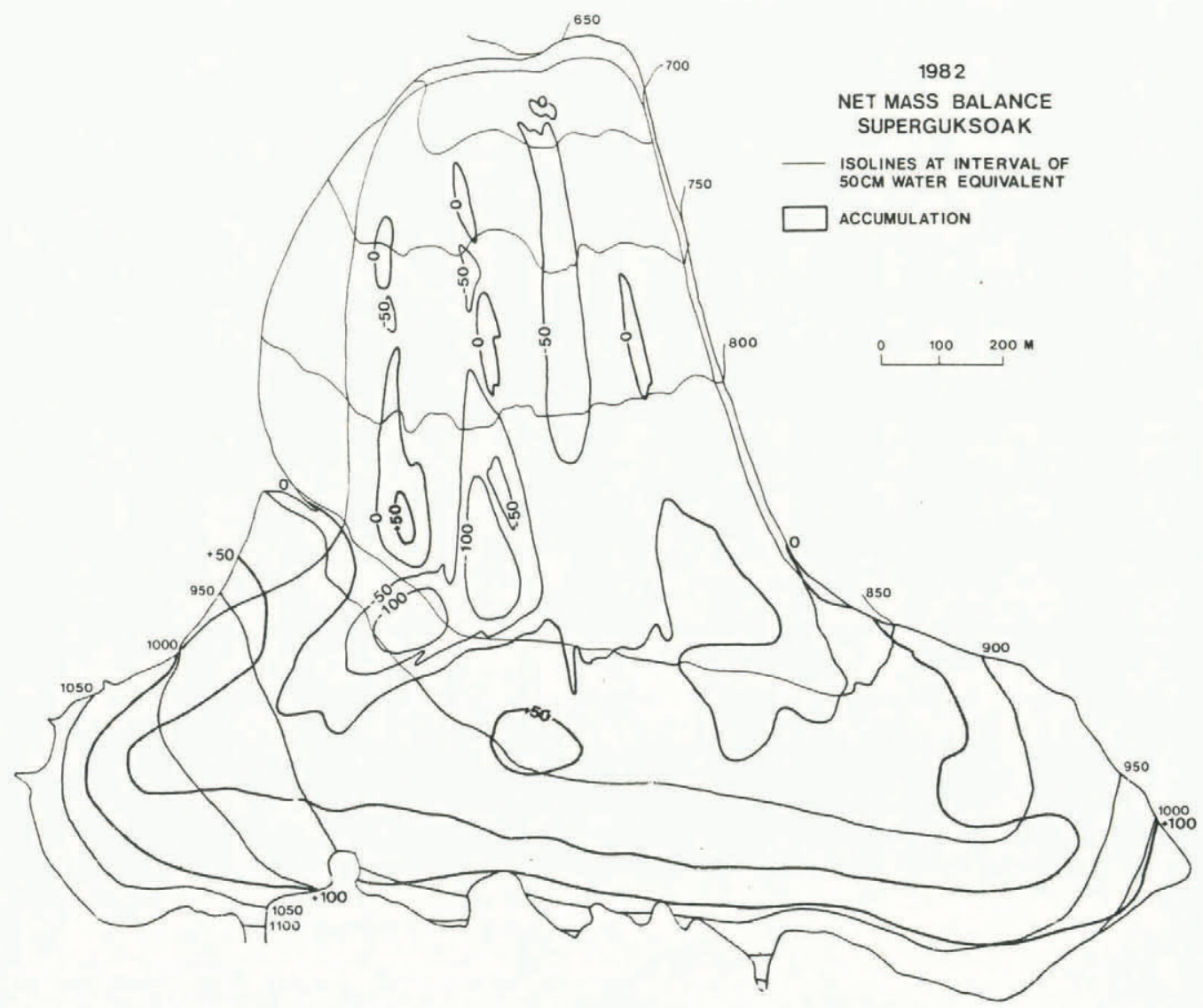

Fig. 7. Map of net mass balance for 1982 for Superguksoak Glacier (see Table II). 
ปัّ้

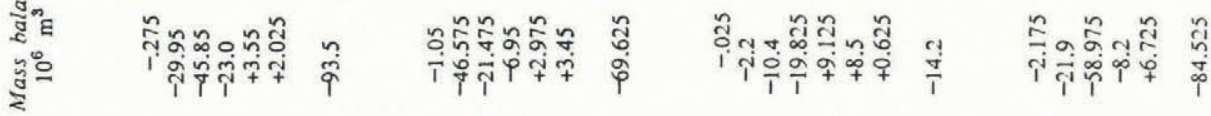

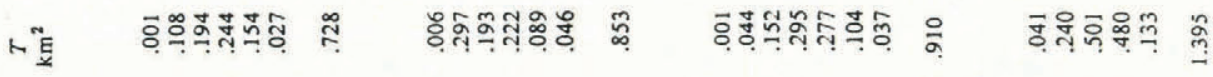

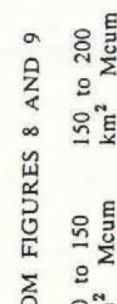

สฺุ

ริ ติ

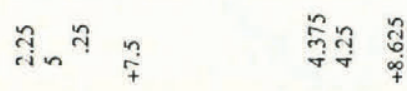

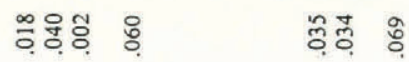

㞾

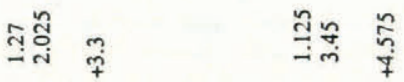

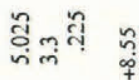

ชำ

ㄷํㅇํำ

웅웅

影骂哭

훙융

פ

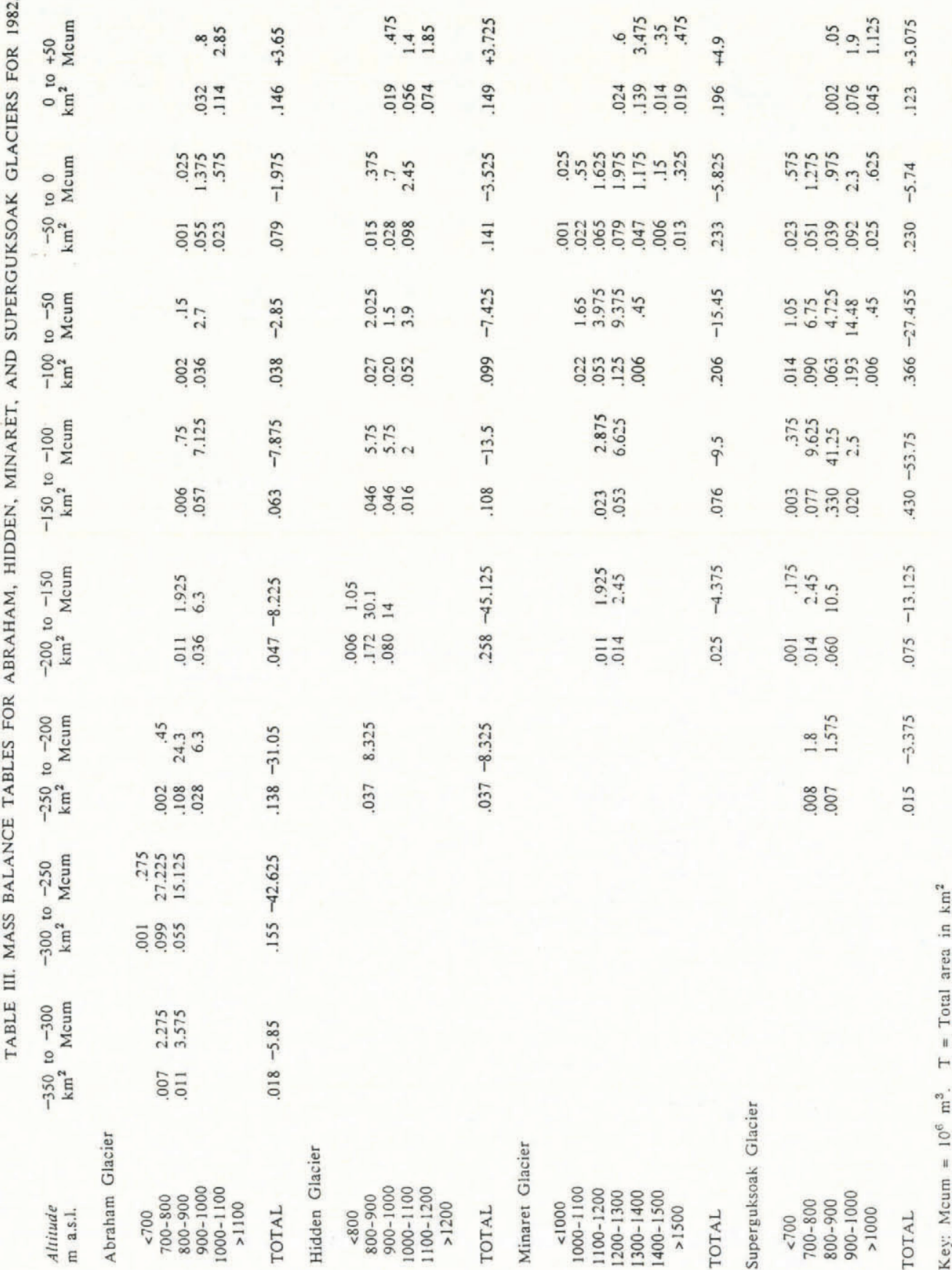




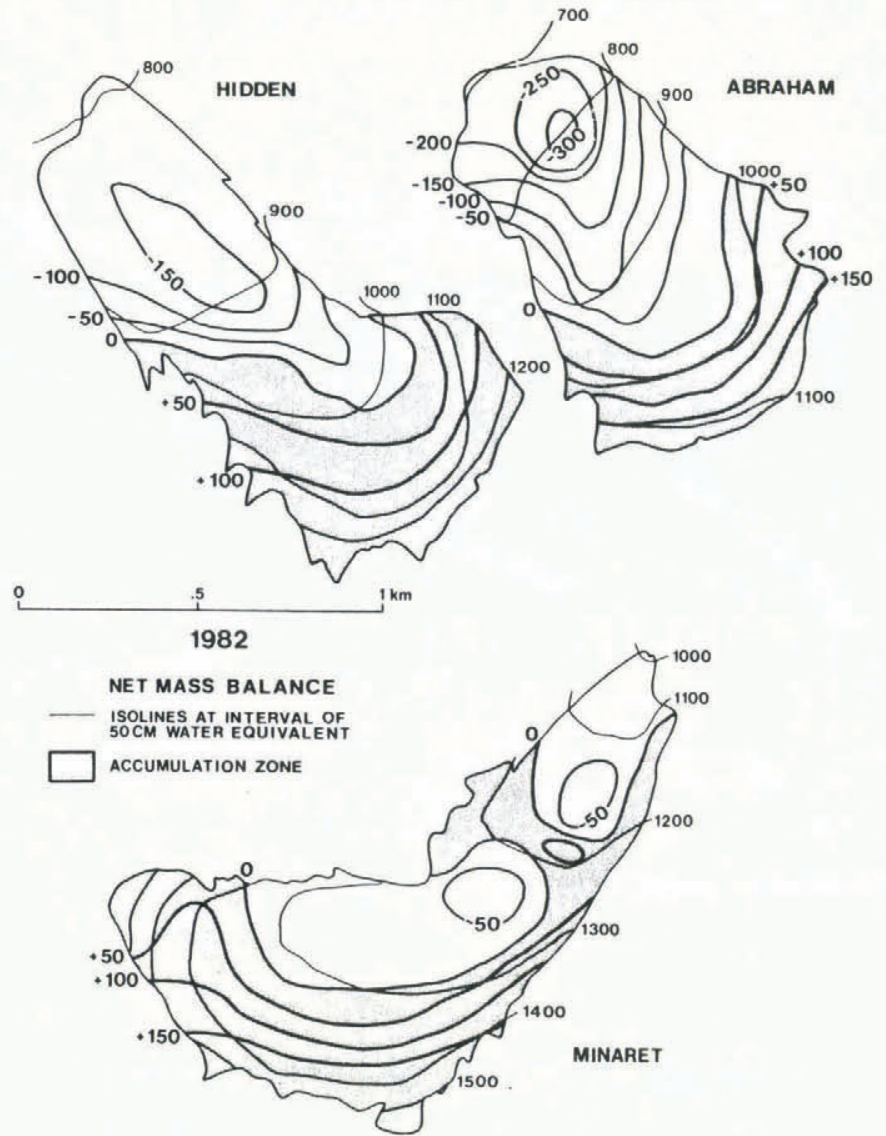

Fig. 8. Maps of net mass balance for 1983 for Abraham, Hidden, and Minaret Glaciers (see Table III).
TABLE IV. NET MASS-BALANCE VALUES, 1981-83, AND CALCULATED MEANS IN METRES WATER EQUIVALENT

$\begin{array}{lccc} & 1981 & 1982 & 1983 \\ \text { Abraham Glacier } & -0.27 & -0.46 & -1.28 \\ \text { Hidden Glacier } & -0.24 & -0.21 & -0.81 \\ \text { Minaret Glacier } & +0.06 & +0.28 & -0.16 \\ \text { Superguksoak Glacier } & -0.06 & +0.28 & -0.16 \\ \text { Mean mass balance } & -0.13 & -0.05 & -0.60\end{array}$

Overall mean for the four glaciers $-0.26 \mathrm{~m}$

large part of most days in July and August. As a consequence, ablation remains fairly constant or increases up-glacier from the terminus (Fig. 9) and reaches maxima where the glacier surface is almost horizontal, near pole 30 and again near poles 50 and 60 . Between these two locations ablation is again reduced although the glacier remains quite level. This appears to be because this area receives much slush from up-glacier which re-freezes to form superimposed ice. In 1983, when slushing was not common on all the glaciers, pole 40 was not so different from its neighbors up and down the glacier.

Minaret Glacier is far higher than the other glaciers studied. It is not overshadowed by high backwalls and therefore, apart from its terminus, experiences long hours of direct solar heating at the surface. The end-of-season snow line is typically much higher than those for the other glaciers, yet is skewed towards the right or southern side of the glacier, as expected. The greater altitude, with cooler temperatures and higher snowfall seems to balance out the greater shading factor of the other glaciers since mass

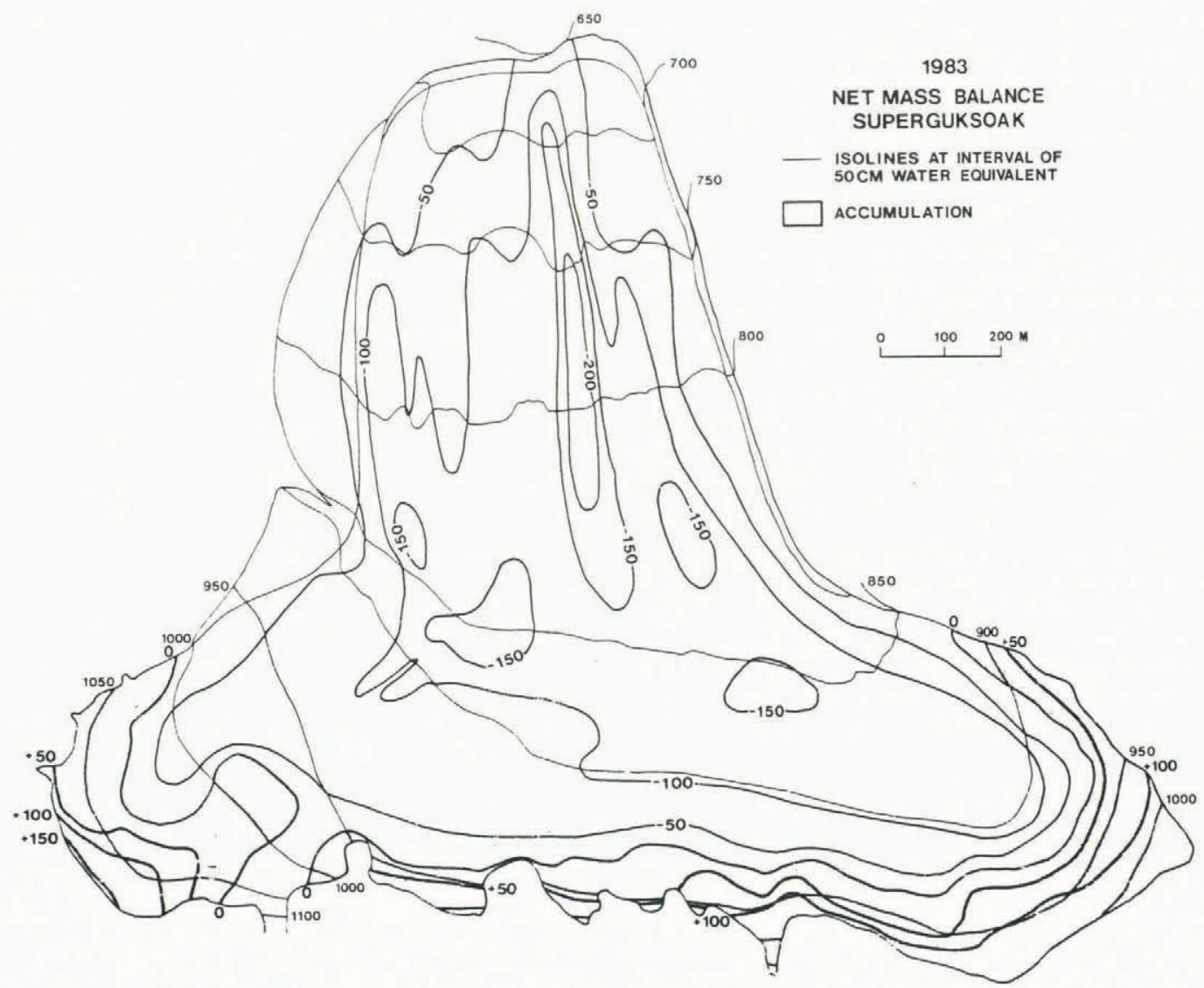

Fig. 9. Map of net mass balance for 1983 for Superguksoak Glacier (see Table III). 


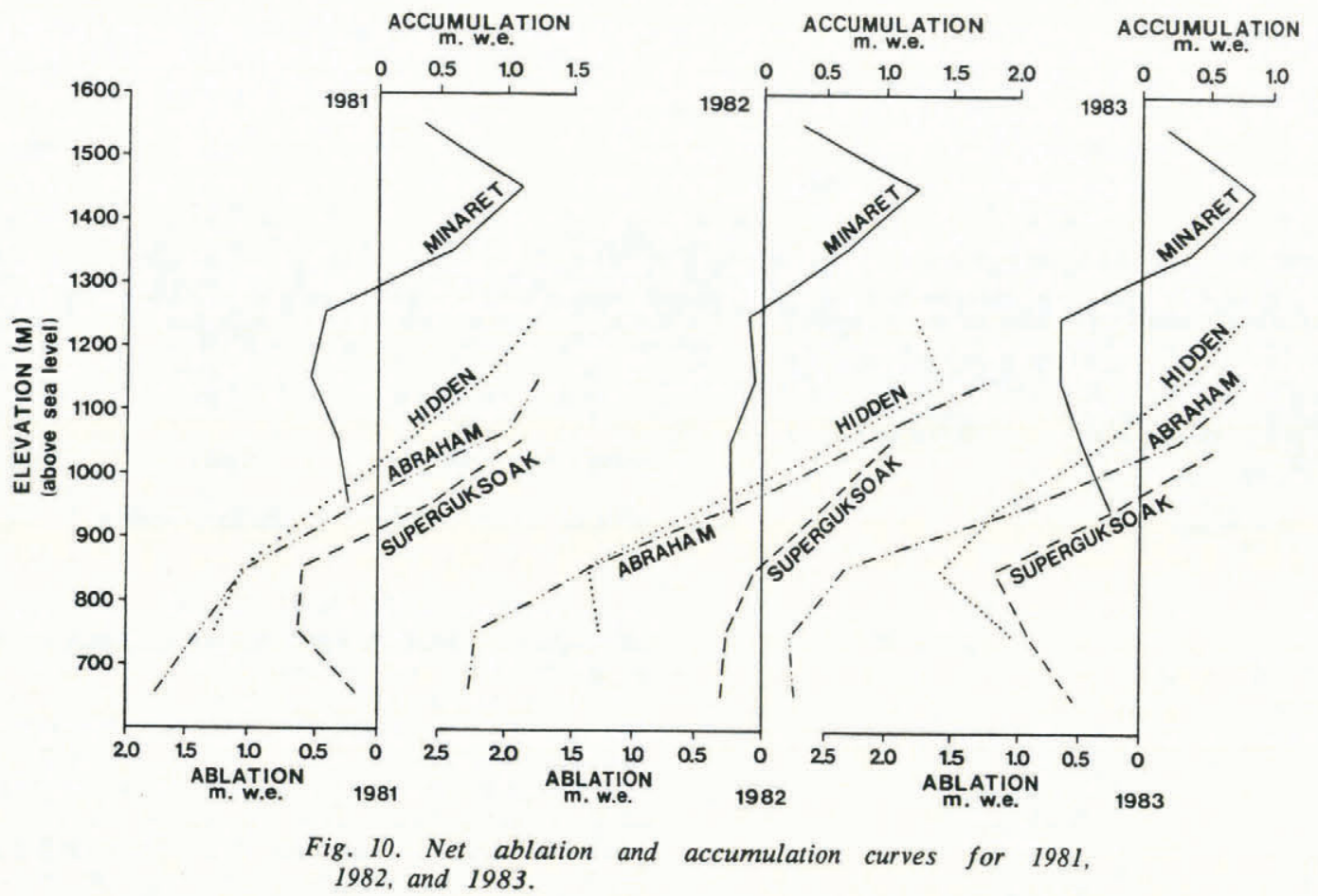

balance is not greatly different for Minaret Glacier than it is for the others.

\section{Hidden Glacier}

Hidden Glacier experienced negative mass balance all three years, with 1983 being the most negative. Here, ablation is greatest towards the north of the glacier centre and the snow line extends much further down-glacier on the southern, shaded side. Ablation is at its greatest immediately above the short medial moraines which cover the lower $0.5 \mathrm{~km}$ of the terminus. Superimposed ice formed in the middle part of the glacier, where the ice is level, in 1981 and 1982 based on the earliest pole readings of the following year. During both summers, this area was covered by slush which accumulated at the foot of a steep step leading up into the accumulation basin.

\section{Abraham Glacier}

Abraham Glacier experienced the highest rates of ablation for any of the glaciers of the Torngat Mountains and consequently the most negative mass balance, reaching a maximum of $-1.28 \mathrm{~mm}$ w.e. in 1983. In excess of $3 \mathrm{~m}$ w.e. of ice melt were measured at pole 10 in 1982 and 1983 . Abraham Glacier also has the steepest mass-balance gradient of all the glaciers (Fig. 10) averaging $>1 \mathrm{~m} / 100 \mathrm{~m}$. The glacier is heavily crevassed, the area of greatest crevassing also being that of greatest melt. Glacier movement has not been accurately measured but probably exceeds $30 \mathrm{~m}$ per year at pole 10 .

Abraham Glacier is the only one of the four which measurably re-advanced during the period 1981-84 (Fig. 11). Four measurement points established in 1981 allowed measurement of a mean re-advance of $1.2 \mathrm{~m} /$ year for three years. At site B a maximum single-year re-advance of $2.8 \mathrm{~m}$ was mesured in 1983. For the terminus as a whole, re-advance appears to be decresing in amount through
1984 .

\section{EQUILIBRIUM LINE ALTITUDES}

Equilibrium line altitudes (ELA) can be obtained from plots of elevation versus mass balance (Fig. 10). They provide a broad indication of macro-climatic conditions and by their variation indicate the extreme variability of microclimatic conditions in a mountainous region (Andrews and Miller, 1972). The overall mean ELA for the glaciers of the Torngat Mountains is $1050 \mathrm{~m}$ (Table V) based on three

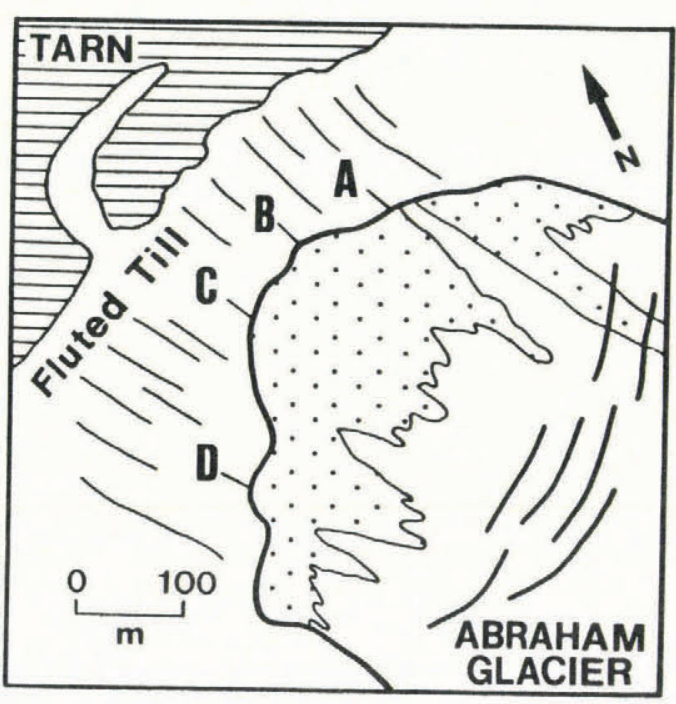

Terminal change (m)

$\begin{array}{lccc} & 1981-82 & 1982-83 & 1983-84 \\ \text { A } & +2.2 & -1.0 & 0 \\ \text { B } & +0.4 & +2.8 & +1.9 \\ \text { C } & +2.4 & +2.2 & +1.4 \\ \text { D } & +0.8 & 0 & 0 \\ \text { Mean } & +1.7 & +1.0 & +0.8 \\ & & (+=\text { advance, }- \text { retreat }) & \end{array}$

Fig. 11. Re-advance observations of the terminus of Abraham Glacier, 1981-84.

years for four glaciers. This mean conceals many variations in both time and space, yet coincides with the estimated elevation of the permanent snow line in the Torngat Mountains made by Ives (1957). The lowest ELA was for Superguksoak Glacier in $1982(860 \mathrm{~m})$ while the highest was for Minaret Glacier in $1983(1320 \mathrm{~m})$, a difference of $460 \mathrm{~m}$. Both of these glaciers had a rise in ELA of $110 \mathrm{~m}$ between 1982 and 1983. On the basis of ELA, 1982 was 
TABLE V. EQUILIBRIUM-LINE ALTITUDES (ELAs), 1981-83, CALCULATED MEANS, AND CIRQUE BACKWALL HEIGHTS

$\begin{array}{ccccc}1981 & 19821983 \quad \text { Mean } & \begin{array}{c}\text { Backwall } \\ \text { height }\end{array} \\ \text { m a.s.l. } & \text { m a.s.l. } & \text { m a.s.l. } & m \text { a.s.1. } & \mathrm{m}\end{array}$

$\begin{array}{lrrrrr}\text { Abraham Glacier } & 960 & 960 & 1030 & 980 & 450 \\ \text { Hidden Glacier } & 1010 & 990 & 1100 & 1030 & 350 \\ \text { Minaret Glacier } & 1290 & 1260 & 1320 & 1290 & 100 \\ \begin{array}{l}\text { Superguksoak } \\ \text { Glacier }\end{array} & 910 & 860 & 970 & 910 & 600\end{array}$

Mean ELA $\quad 1040 \quad 1020 \quad 1110 \quad 1050$

the best year overall for glacier accumulation, whilst 1983 was the best for ablation.

The ELA for Minaret Glacier is probably close to a "regional" ELA, while those for the other three, which are all quite similar, probably represent the effects of shading. On average they are $c .340 \mathrm{~m}$ lower than the ELA for Minaret Glacier. Using an approximate rate of ELA decline of $100 \mathrm{~m}$ per degree latitude, taken from Sugden and John (1976, Figure 5.5), the differences represent $c .3 .4$ degrees of latitude, or $>350 \mathrm{~km}$. In general, the "shaded" ELAs are similar to those for the Cumberland Peninsula of Baffin Island (Andrews and Miller, 1972), whilst the ELA for Minaret Glacier is substantially higher than any on Baffin Island. Shading may be the controlling factor in the survival of most Torngate Mountain glaciers.

\section{CLIMATIC CONDITIONS}

No climate stations were established on or near the glaciers during the mass-balance program. General conditions which prevailed during the summers can be ascertained from the analysis of daily field observations of weather, but are better obtained from the general record of Canadian monthly climate summaries (Table VI).

Mass-balance year 1981 began with a warm, snowy winter followed by a cool, wet spring and warm, dry summer. The early winter following was also warm and snowy but was followed by a cold spring in 1982 with a single wet month, April, and a summer which was average in both precipitation and temperature. The major differences between 1981 and 1982 were summer conditions and they resulted in a slightly less negative mass-balance regime in 1982. Mass-balance year 1983 began with a very cold and dry winter which culminated in a wet spring and temperatures far above normal in April, probably associated with rain. Summer 1983 was also average to wet and, although June temperatures were above normal, the remainder of the summer was normal to slightly cooler than normal. Since 1983 was the largest negative year, the major differences between it and the others are winter precipitation and temperature, and possibly April temperature. Of these, winter precipitation is probably most important. High temperatures in March 1981, following a snowy winter, did not have the effect of high temperatures in April 1983, which followed a dry winter.

Departure from mean temperature for each mass-balance year is not a useful indicator of mass balance. The coldest year was $1983(-1.5 \mathrm{deg}$ departure) while the warmest was 1981 (+0.5 deg departure). Qualitative observations of snow conditions in July, even high in the accumulation basins of the glaciers, tend to confirm the view that winter precipitation is the controlling climatic variable in mass balance.

\section{CONCLUSIONS}

Mass balance for the Torngat Mountains glaciers is at present generally negative, averaging $-0.26 \mathrm{~m}$ overall between 1981 and 1984. The two largest glaciers may experience
TABLE VI. CLIMATIC SUMMARY, OCTOBER 1980 TO SEPTEMBER 1983, FOR THE TORNGAT MOUNTAINS

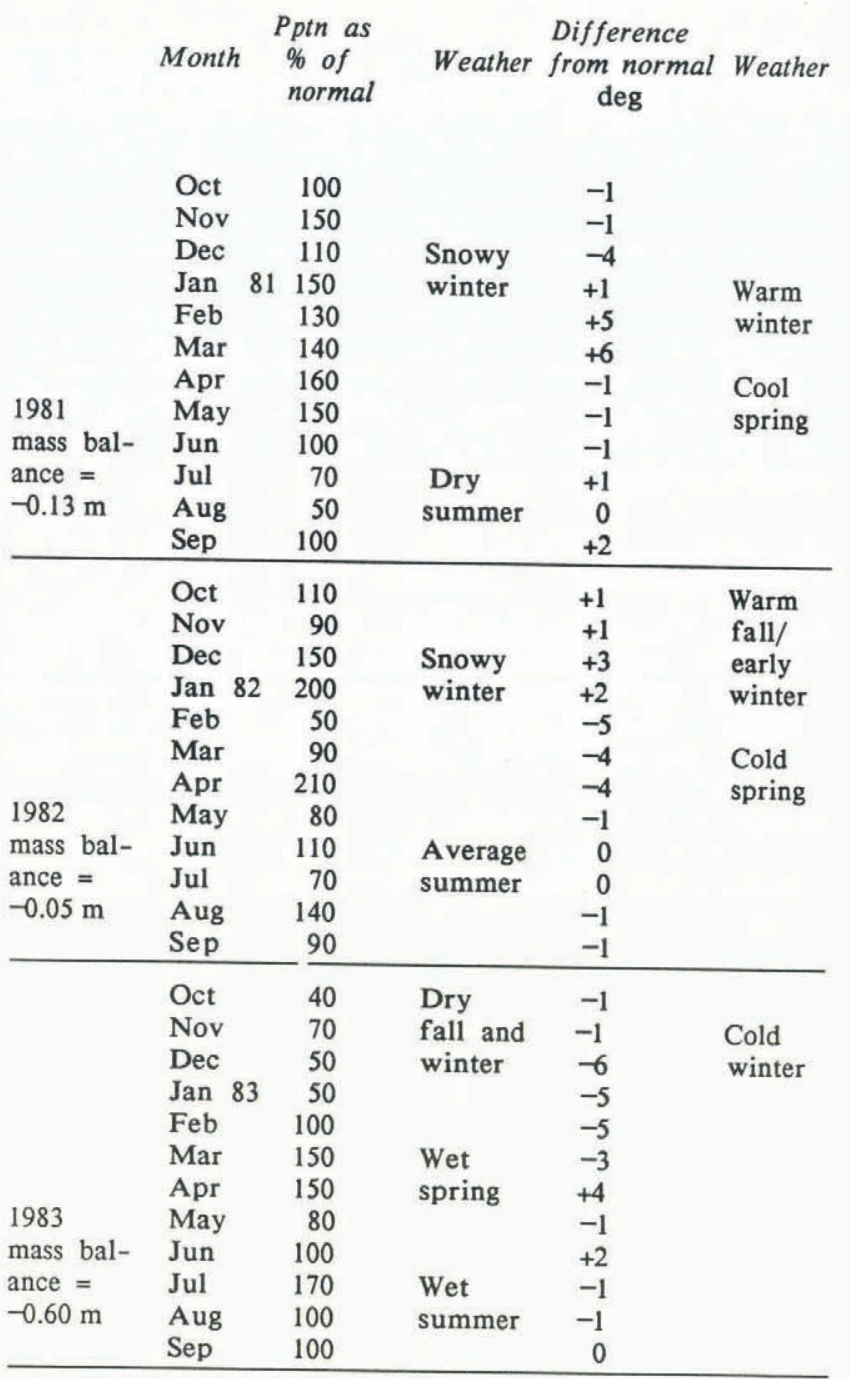

Values interpreted to the nearest $10 \%$ or nearest whole ${ }^{\circ} \mathrm{C}$ from summary maps in the Monthly Weather Review, Atmospheric Environment Service, Environment Canada, Vol. 18-20, and the Monthly Supplement to Climatic Perspectives, Vol. 5.

positive mass balances up to $+0.28 \mathrm{~m}$ when a climatically average summer follows a snowy winter. Mass balance does not appear to be inversely related to mean annual temperature.

Most glaciers of the Torngat Mountains have ELAs approximately $1000 \mathrm{~m}$ a.s.l. These are low for such a low latitude $\left(59^{\circ} \mathrm{N}\right.$. ), probably because the glaciers are overshadowed by high cirque backwalls which decrease summer melt. Minaret Glacier, with only minor shading, has an ELA approximately $340 \mathrm{~m}$ higher and its terminus is at approximately the same altitude as the highest and most shaded parts of the accumulation zones of the other glaciers.

Abraham Glacier is re-advancing up to $2.7 \mathrm{~m}$ in one year despite current negative mass balance. This must be in response to antecedent conditions which may have paralleled those reported from elsewhere in the eastern Arctic during the mid 1960s and through the 1970s. The other glaciers show no signs of re-advance or retreat.

The survival of glaciers in the Torngat Mountains seems likely for the immediate future even if climate improves slightly. Warmer temperatures in the winter could cause high snowfalls, as in January 1982 and 1983. Furthermore, even if higher temperatures caused much melt and substantially eroded the glaciers, any reduction in the 
surface elevation of the glaciers would increase the amount of shading and eventually depress the ELA even further.

\section{ACKNOWLEDGEMENTS}

The investigation of mass balance in the Torngat Mountains was supported by Natural Sciences Engineering Research Council of Canada operating grants A6105 for 4 years, and in 1981 by a small contract with the Snow and Ice Division of Environment Canada. The Northern Scientific Training grants supported a number of students to work on the glaciers, and the Newfoundland Department of Mines and Energy and PetroCanada Explorations provided valuable support in transportation and communications. Assistants who worked long and hard in the field were $\mathbf{M}$. Olson, E. Guy (1981), H. Russell (1982 and 1983), T. Kelliher (1982), D. Branson (1983), L. St. Croix (1983 and 1984), L. Davis and C. Garrity (1984). S. Halliday drafted the diagrams.

\section{REFERENCES}

Andrews, J.T., and Miller, G.H. 1972. Quaternary history of northern Cumberland Peninsula, Baffin Island, N.W.T., Canada: part IV: maps of the present glaciation limits and lowest equilibrium line altitude for north and south Baffin Island. Arctic and Alpine Research, Vol. 4, No. 1, p. 45-59.

Bradley, R.S., and England, J. 1977. Past glacial activity in the high Arctic. Amherst, MA, University of Massachusetts. Department of Geology and Geography. (Contribution No. 31.)
Bradley, R.S., and Miller, G.H. 1972. Recent climatic change and increased glacierization in the eastern Canadian Arctic. Nature, Vol. 237, No. 5355, p. 385-87.

Branson, D. Unpublished. Magnitude and characteristics of ablation on four Torngat glaciers. [B.A. Hons. Dissertation, Cambridge, 1984.]

Fahn, C. 1975. Glaciers of northern Labrador. (In Field, W.O., ed. Mountain glaciers of the northern hemisphere. Vol. 2. Hanover, NH, Cold Regions Research and Engineering Laboratory, p. 673-82.)

Ives, J.D. 1957. Glaciation of the Torngat Mountains, northern Labrador. Arctic, Vol. 10, No. 2, p. 66-87.

Mercer, J.H. Unpublished. The glaciers of northern Labrador. (In Geographic study of mountain glaciation in the northern hemisphere. New York, American Geographical Society, p. 2b.3.1.-2b.3.4.)

Østrem, G., and Stanley, A. 1966. Glacier mass balance measurements; a manual for field work. [Ottawa], Department of Mines and Technical Surveys. Glaciology Section.

Rogerson, R.J., and others. In press. Medial moraines and surface melt on glaciers of the Torngat Mountains, northern Labrador, Canada, by R.J. Rogerson, M.E. Olson, and D. Branson. Journal of Glaciology.

Stix, J. Unpublished. Glaciers of the Nachvak Fiord region, northern Labrador. Ottawa, Environment Canada. National Hydrology Research Institute. Snow and Ice Division. (Draft Report.)

Sugden, D.E., and John, B.S. 1976. Glaciers and landscape; a geomorphological approach. London, Edward Arnold.

Tanner, V. 1944. Outlines of the geography, life and customs of Newfoundland-Labrador (the eastern part of the Labrador Peninsula.) Acta Geographica, 8, No. 1. 